\title{
PENGARUH PEMBERIAN EKSTRAK TEMULAWAK (CURCUMA XANTHORRHIZA ROXB) TERHADAP MORTALITAS DAN GAMBARAN DARAH BENIH IKAN NILEM (OSTEOCHILUS HASSELTI) DENGAN UJI TANTANG MENGGUNAKAN BAKTERI AEROMONAS HYDROPHILA
}

\section{THE EFFECT OF EXTRACTS OF TURMERIC (CURCUMA XANTHORRHIZA ROXB) AGAINST THE MORTALITY RATE AND BLOOD PICTURE OF NILEM (OSTEOCHILUS HASSELTI) FRY THAT HAD BEEN CHALLENGED BY AEROMONAS HYDROPHILA BACTERIA}

\author{
Galih Permana Putra $^{1 a}$, Mulyana ${ }^{1}$, Fia Sri Mumpuni ${ }^{1}$ \\ ${ }^{1 a, 1}$ Jurusan Perikanan, Fakultas Pertanian, Universitas Djuanda Bogor \\ Jalan Tol Ciawi 1, Kotak Pos 35 Bogor 16720
}

Korespondensi: Galih Permana Putra, E-mail: permanagalih067@gmail.com (Diterima: 08-10-2015, Ditelaah: 13-10-2015, Disetujui: 17-10-2015)

\begin{abstract}
ABSTRAK
Penelitian ini dilaksanakan di Laboratorium Perikanan, Fakultas Pertanian, Universitas Djuanda Bogor, pada bulan Agustus 2014 - September 2015. Tujuan penelitian ini adalah untuk mengetahui pengaruh pemberian ekstrak temulawak (Curcuma xanthorriza Roxb) yang dicampur ke dalam pakan terhadap tingkat mortalitas dan gambaran darah benih ikan nilem (Osteochilus hasselti) setelah diinfeksi Aeromonas hydrophila. Penelitian percobaan ini menggunakan Rancangan Acak Lengkap dengan 4 perlakuan dan tiga ulangan. Perlakuan ini adalah Kontrol (tanpa temulawak), A (dosis $1 \mathrm{~mL} / \mathrm{kg}$ pakan), B (dosis $3 \mathrm{~mL} / \mathrm{kg}$ pakan), dan C (dosis $5 \mathrm{~mL} / \mathrm{kg}$ pakan). Hasil penelitian memperlihatkan bahwa tidak ada perbedaan yang nyata $(\mathrm{P}>0,05)$ diantara perlakuan terhadap mortalitas, total leukosit, hemoglobin dan hematokrit.
\end{abstract}

Kata kunci: Ikan nilem, temulawak, Aeromonas hydrophila, pakan.

\section{ABSTRACT}

The research is aimed to determine the effect of ginger (Curcuma xanthorrhiza Roxb) extract supplementation in the feed against the mortality rate and blood picture of nilem (Osteochilus hasselti) fry after infected by Aeromonas hydrophila bacteria. This research was done at the Laboratory of Fisheries, Faculty of Agriculture, University of Djuanda Bogor, in August 2014 - September 2015. The experiment design used in the study were completely randomized design with 4 treatments and 3 replications. The treatments were Control (with out ginger), A (1 mL of ginger $/ \mathrm{kg}$ feed), B (3 mL of ginger $/ \mathrm{kg}$ feed), and $\mathrm{C}(5 \mathrm{~mL}$ of ginger $/ \mathrm{kg}$ feed). The results of research showed there were not significantly different between treatments for mortality, the total leukocyte, hemoglobine, and hematocrite $(\mathrm{P}>0.05)$.

Keywords: Nilem fry, ginger, Aeromonas hydrophila, feed.

Galih PP et.al. 2015. PENGARUH PEMBERIAN EKSTRAK TEMULAWAK (CURCUMA XANTHORRHIZA ROXB) TERHADAP MORTALITAS DAN GAMBARAN DARAH BENIH IKAN NILEM (OSTEOCHILUS HASSELTI) DENGAN UJI TANTANG MENGGUNAKAN BAKTERI AEROMONAS HYDROPHILA. Jurnal Mina Sains 1(2): 6778. 


\section{PENDAHULUAN}

Ikan nilem (Osteochilus vittatus) merupakan ikan air tawar yang termasuk ke dalam famili Cyprinidae yang bersifat herbivora. Ikan ini menyebar di Asia Tenggara, di Indonesia nilem merupakan ikan budidaya untuk konsumsi, terutama di Jawa Barat. Nilai ekonomis ikan nilem meningkat setelah dijadikan produk olahan misalnya baby fish goreng, dendeng dan pindang, diasap dan dikalengkan. Dari aspek lingkungan ikan nilem berperan sebagai biocleaning agent karena sifatnya yang suka memakan detritus dan perifiton dan juga ikan pintar yang dapat membersihkan kulit dari kotoran dan sel-sel kulit yang telah mati (Cholik et al. 2005).

Indikator keberhasilan dalam usaha budidaya ikan adalah kondisi kesehatan ikan. Oleh karena itu, masalah penyakit merupakan masalah yang sangat penting untuk ditangani secara serius. Penyakit pada ikan merupakan salah satu masalah yang sering dijumpai dalam usaha budidaya ikan. Di Indonesia telah diketahui ada beberapa jenis ikan air tawar, dan diantaranya sering menimbulkan penyakit serta menyebabkan kegagalan dalam usaha budidaya. Penyakit bakterial merupakan salah satu penyakit yang dapat menimbulkan kerugian yang tidak sedikit.

Menurut Angka (2004a) Aeromonas sp. merupakan bakteri patogen dan sering menjadi penyebab penyakit pada ikan-ikan air tawar. Salah satu bakteri yang sering menyerang ikan air tawar adalah Aeromonas hydrophila yang menyebabkan penyakit Motile Aeromonas Septicemia (MAS) atau penyakit bercak merah pada tubuh ikan. Bakteri ini menyerang berbagai jenis dan ukuran ikan air tawar seperti lele dumbo (Clarias gariepinus), ikan mas (Cyprinus caprio), gurami (Osphronemus gouramy), nilem (Osteochilus vittatus), dan udang galah (Macrobrachium rosenbergii) yang dapat menimbulkan wabah penyakit dengan tingkat kematian tinggi (80-100\%) dalam waktu 1-2 minggu. Pengendalian bakteri ini sulit karena memiliki banyak strain dan selalu ada di air serta dapat menjadi resisten terhadap obat-obatan (Kamiso et al. 1993).

Beberapa obat kimiawi dan bahan alami yang berasal dari tanaman obat atau herbal telah banyak dipakai dan diketahui untuk pencegahan dan pengobatan penyakit infektif maupun non infektif pada komoditas perikanan yang dibudidaya. Tanaman obat herbal sering digunakan sebagai alternatif pengobatan karena tidak memiliki residu yang berbahaya dibandingkan obat berbahan kimiawi.

Temulawak (Curcuma xanthorrhiza Roxb.) diketahui mengandung zat antimikroba, salah satu kandungannya adalah kurkumin yang dapat menghambat pertumbuhan dan mematikan mikroorganisme (Ardiansyah, 2007). Menurut Melisa (2008) temulawak pernah diujikan aktifitas anti bakterinya terhadap beberapa bakteri seperti Escherchia coli, Bacillus cereus, Salmonella thypi, dan Klebsiella pneumonia. 
Penggunaan tanaman untuk pengobatan telah lama dikenal oleh masyarakat. Usaha pengembangan tanaman untuk pengobatan perlu dilakukan mengingat bahwa tanaman mudah diperoleh dan murah. Tetapi penggunaan tanaman untuk pengobatan perlu ditunjang oleh data-data penelitian dari tanaman tersebut sehingga khasiatnya secara ilmiah tidak diragukan lagi dan dapat dipertanggungjawab-kan. Hal ini akan mendorong penggunaan bahan alami sebagai obat secara meluas oleh masyarakat dan juga dapat digunakan untuk mencegah atau mengobati hewan khususnya ikan. Oleh karena itu, pada penelitian ini digunakan ekstrak temulawak sebagai obat herbal alami yang sudah banyak manfaatnya terhadap manusia, diharapkan dapat menekan bakteri Aeromonas hydrophila pada benih ikan nilem juga.

Tujuan penelitian ini untuk mendapatkan konsentrasi ekstrak temulawak yang efektif untuk mengobati penyakit pada benih ikan nilem yang terinfeksi bakteri Aeromonas hydrophila sehingga menghasilkan kelangsungan hidup benih nilem tertinggi.

Pada temulawak terdapat kandungan kurkumin yang bermanfaat sebagai anti radang, dan juga terdapat kandungan xanthorrhizol yang berperan sebagai anti bakteri dan anti jamur, sehingga diharapkan dapat mengatasi permasalahan kematian ikan yang disebabkan oleh bakteri Aeromonas hydrophila.

\section{MATERI DAN METODE}

\section{Waktu dan Tempat}

Penelitian ini dilaksanakan di Laboratorium Perikanan, Fakultas Pertanian, Universitas Djuanda Bogor. Penelitian dilakukan pada bulan Agustus 2014 sampai dengan bulan September 2015.

\section{Alat dan Bahan}

Peralatan yang akan digunakan dalam penelitian adalah wadah pemeliharaan berupa akuarium sebanyak 12 unit dengan ukuran $50 \mathrm{~cm} \times 30 \mathrm{~cm} \times 30 \mathrm{~cm}$, timbangan digital, syringe volume $0,5 \mathrm{~mL}$, pompa aerator, selang aerasi, batu aerator, selang plastik, $\mathrm{pH}$ meter, termometer, DO meter, serta gayung dan seser.

Bahan yang digunakan dalam penelitian adalah benih ikan nilem berukuran $7-8 \mathrm{~cm}$, isolat Aeromonas hydrophila, ekstrak temulawak berupa oleoresin, bahan-bahan untuk titrasi DO dan pakan komersil (protein kasar $27 \%)$.

\section{Penelitian Pendahuluan}

Sebelum masuk ke percobaan utama, terlebih dulu dilakukan uji LD-50. Uji ini dilakukan untuk mengetahui pada konsentrasi berapa bakteri Aeromonas hydrophila menyebabkan patogen pada ikan uji dan dapat menyebabkan kematian ikan uji sebanyak 50\%. Dari uji ini, dapat ditentukan konsentrasi bakteri yang akan diinfeksikan pada uji tantang penelitian utama. Selain itu, dari uji ini juga dapat diketahui virulensi dari bakteri yang digunakan. Bakteri yang digunakan adalah $A$. hydrophila dengan kode isolat A3 yang 
merupakan koleksi Laboratorium Patologi BPPBAT Sempur, Bogor.

Penentuan uji LD-50 dilakukan dengan cara menyuntikan A. hydrophila pada ikan nilem dengan konsentrasi $10^{3}, 10^{4}, 10^{5}, 10^{6}$, $10^{7}$, dan $10^{8} \mathrm{sel} / \mathrm{mL}$ sebanyak $0.1 \mathrm{~mL} /$ ekor secara intramuskular masing-masing sebanyak 10 ekor ikan tiap perlakuan sehingga didapatkan isolat yang paling virulen untuk digunakan pada uji tantang penelitian utama, sebagai pembanding disediakan perlakuan kontrol. Bakteri diinfeksi ke ikan dengan cara menyuntikkannya pada bagian punggung ikan (intramuskular) sebanyak $0.1 \mathrm{~mL} / \mathrm{ikan}$. Pengamatan dilakukan selama 96 jam dengan menghitung jumlah ikan yang mati pada masing-masing konsentrasi $10^{3}, 10^{4}, 10^{5}, 10^{6}$, $10^{7}$, dan $10^{8} \mathrm{sel} / \mathrm{mL}$ sehingga dapat diketahui isolat yang paling virulen. Isolat yang paling virulen dipilih untuk digunakan pada uji tantang penelitian utama.

\section{Rancangan Penelitian}

Penelitian menggunakan rancangan percobaan berupa Rancangan Acak Lengkap (RAL) yang terdiri dari 4 perlakuan dengan 3 kali ulangan, masing-masing unit percobaan menggunakan 10 ekor benih ikan nilem. Perlakuan yang dilakukan adalah penambahan ekstrak temulawak pada pakan buatan dengan konsentrasi berbeda. Rancangan penelitian yang akan dilakukan dapat dilihat pada Tabel 1.

Tabel 1 Rancangan perlakuan pemberian ekstrak temulawak dengan konsentrasi berbeda pada media pemeliharaan benih ikan nilem

\begin{tabular}{c|l} 
Perlakuan & \multicolumn{1}{|c}{ Keterangan } \\
\hline $\mathrm{K}$ & Pemeliharaan benih ikan nilem tanpa pemberian ekstrak temulawak \\
\hline $\mathrm{A}$ & Pemeliharaan benih ikan nilem dengan pemberian ekstrak temulawak sebanyak 1 g/kg pakan \\
\hline $\mathrm{B}$ & Pemeliharaan benih ikan nilem dengan pemberian ekstrak temulawak sebanyak 3 g/kg pakan \\
\hline $\mathrm{C}$ & Pemeliharaan benih ikan nilem dengan pemberian ekstrak temulawak sebanyak 5 g/kg pakan
\end{tabular}

Model persamaan linier berdasarkan Still dan yang pernah dilakukan sebelumnya oleh Yani Torrie (1991) adalah sebagai berikut: et al. (2012).

$$
\mathbf{Y}_{\mathrm{ij}}=\boldsymbol{\mu}+\boldsymbol{\delta}_{\mathrm{i}}+\dot{\varepsilon}_{\mathrm{ij}}
$$

\section{Keterangan :}

$\mathrm{Y}_{\mathrm{ij}}=$ Data hasil pengamatan pada perlakuan ke-i dan ulangan ke-j

$\mu=$ Nilai tengah dari populasi

$\delta_{\mathrm{i}}=$ Pengaruh perlakuan ke-i

$\dot{\varepsilon}_{\mathrm{ij}}=$ Galat perlakuan ke-i dan ulangan ke-j

$\mathrm{i}=$ Perlakuan $(\mathrm{i}=\mathrm{K}, \mathrm{A}, \mathrm{B}, \mathrm{C})$

$\mathrm{j}=$ Ulangan $(\mathrm{j}=1,2,3)$

Pemberian dosis temulawak didasari dari penelitian pengaruh pemberian temulawak

\section{Parameter Pengamatan}

\section{Mortalitas}

Menghitung mortalitas menggunakan rumus sebagai berikut:

Sumber: Effendie (1997)

$$
M o=\frac{M t}{N o}
$$

Keterangan:

$\mathrm{M}_{\mathrm{o}}=$ Tingkat kematian ikan (\%)

$\mathrm{M}_{\mathrm{t}}=$ Jumlah ikan mati (ekor)

$\mathrm{N}_{\mathrm{o}}=$ Populasi ikan pada hari ke-0 (ekor)

\section{Kualitas Air}


Kualitas air yang diukur pada penelitian ini ialah suhu, DO, dan $\mathrm{pH}$. Parameter suhu diukur dengan menggunakan termometer, DO diukur dengan $\mathrm{DO}$ meter, dan $\mathrm{pH}$ diukur dengan $\mathrm{pH}$ meter. Pengukuran dilakukan 3 kali pengulangan selama pemeliharaan ikan, yaitu pada awal pemeliharaan, pertengahan pemeliharaan, dan akhir pemeliharaan.

\section{Gambaran Darah}

\section{Total sel darah putih (Leukosit)}

Penghitungan total leukosit dilakukan menurut metode Svobodova \& Vyukusova (1991). Darah dihisap dengan pipet yang berisi bulir pengaduk warna putih sampai skala 0,5 . Lalu ditambahkan larutan Turk's (berfungsi untuk mematikan sel-sel darah merah) sampai skala 11, pengadukan darah di dalam pipet dilakukan dengan mengayunkan tangan yang memegang pipet seperti membentuk angka delapan selama 3-5 menit sampai darah tercampur rata. Tetesan pertama larutan darah dalam pipet dibuang, selanjutnya larutan diteteskan pada haemacytometer tipe Neubauer kemudian ditutup dengan gelas penutup. Jumlah sel darah putih dihitung dengan bantuan mikroskop dengan perbesaran 400 kali. Jumlah leukosit total dihitung sebanyak 5 kotak besar dan jumlahnya dihitung dengan rumus: Total leukosit $=$ jumlah sel terhitung $\mathrm{x}$ $50 \mathrm{sel} / \mathrm{mm}^{3}$.

\section{Hemoglobin (Hb)}

Konsentrasi hemoglobin diukur menggunakan metode Sahli. Sampel darah ikan diambil dengan pipet sahli sampai skala
$20 \mathrm{~mm}^{3}$. Ujung pipet yang digunakan dibersihkan dari sisa-sisa darah dengan kertas tissue. Darah dipindahkan ke dalam tabung sahli yang telah diisi dengan $\mathrm{HCl} 0,1 \mathrm{~N}$ sampai angka 10 (garis skala paling bawah pada tabung sahli). Kemudian tabung tersebut ditempatkan diantara 2 tabung yang berisi warna standar. Akuades ditambahkan ke dalam tabung sahli sedikit demi sedikit menggunakan pipet, samapi warnanya sama dengan warna standar, dan hasilnya dinyatakan dalam g\% (Hesser 1960).

\section{Kadar hematokrit (Ht)}

Sampel darah ikan dihisap menggunakan tabung mikrohematokrit berlapis heparin dengan kapiler. Fungsi heparin adalah untuk mencegah pembekuan darah di dalam tabung. Setelah darah mencapai $3 / 4$ bagian tabung, kemudian salah satu ujung tanbung disumbat dengan critoscal. Tabung kapiler yang berisi darah kemudian disentrifusi pada 600 rpm selama 5 menit. Pengukuran dilakukan dengan membandingkan volume sel darah terhadap seluruh darah dengan menggunakan skala hematokrit (Anderson dan Siwicky 1993).

\section{Analisa Data}

Mortalitas dan gambaran darah dianalisis dengan menggunakan analisis ragam (ANOVA) dan jika berbeda nyata dilanjutkan dengan uji lanjut Beda Nyata Terkecil (BNT) untuk melihat perbedaan antar perlakuan. 


\section{HASIL DAN PEMBAHASAN}

Penelitian pendahuluan dilakukan menggunakan ikan nilem berukuran $7-8 \mathrm{~cm}$ dengan parameter yang diamati yaitu tingkat kematian selama 96 jam pemeliharaan setelah disuntikan bakteri A. hydrophila. Hasil yang diperoleh yaitu dosis $10^{7} \mathrm{sel} / \mathrm{mL}$ sebesar $60 \%$, dan dosis $10^{8} \mathrm{sel} / \mathrm{mL}$ sebesar $90 \%$ (Tabel 2).

Tabel 2 Mortalitas (\%) benih nilem pasca penyuntikan A. hydrophila

\begin{tabular}{|c|c|c|}
\hline No & Perlakuan & Mortalitas (\%) \\
\hline 1 & A (kontrol) & 0 \\
\hline 2 & $\mathrm{~B}\left(\operatorname{dosis} 10^{3} \mathrm{sel} / \mathrm{mL}\right)$ & 0 \\
\hline 3 & $\mathrm{C}\left(\right.$ dosis $\left.10^{4} \mathrm{sel} / \mathrm{mL}\right)$ & 0 \\
\hline 4 & $\mathrm{D}\left(\operatorname{dosis} 10^{5} \mathrm{sel} / \mathrm{mL}\right)$ & 0 \\
\hline 5 & $\mathrm{E}\left(\operatorname{dosis} 10^{6} \mathrm{sel} / \mathrm{mL}\right)$ & 0 \\
\hline 6 & $\mathrm{~F}\left(\operatorname{dosis} 10^{7} \mathrm{sel} / \mathrm{mL}\right)$ & 60 \\
\hline 7 & $\mathrm{G}\left(\operatorname{dosis} 10^{8} \mathrm{sel} / \mathrm{mL}\right)$ & 90 \\
\hline
\end{tabular}

hydrophila yang digunakan, maka semakin tinggi pula tingkat kematian benih ikan nilem. Namun pada pengamatan $L_{50}$ ini tidak memperoleh tingkat kematian 50\%, maka dari itu dipilih dosis yang paling mendekati mortalitas $50 \%$ yaitu perlakuan $\mathrm{F}\left(10^{7} \mathrm{sel} / \mathrm{mL}\right)$ sebagai dosis $\mathrm{LD}_{50}$ dengan mortalitas sebesar $60 \%$. Hasil dari uji $\mathrm{LD}_{50}$ ini digunakan pada uji tantang benih nilem yang sudah diberi perlakuan pemberian ekstrak temulawak pada pakan komersil yang sudah direpeleting.

\section{Penelitian Utama}

\section{Mortalitas}

Benih ikan nilem yang sudah dipelihara selama 30 hari dan diberi perlakuan pemberian ekstrak temulawak pada pelet selanjutnya dilakukan uji tantang dengan menggunakan bakteri $A$. hydrophila pada $\mathrm{LD}_{50}\left(10^{7} \mathrm{sel} / \mathrm{mL}\right)$ untuk uji tantang pertama. Data mortalitas ikan nilem diamati selama 96 jam pengamatan pada uji tantang pertama dapat dilihat pada Tabel 3. Tabel 3 Mortalitas (\%) benih ikan nilem pada uji tantang pertama

\begin{tabular}{ccccc}
\hline \multirow{2}{*}{ Ulangan } & \multicolumn{5}{c}{ Perlakuan } \\
\cline { 2 - 5 } & $\mathbf{K}$ & $\mathbf{A}$ & $\mathbf{B}$ & $\mathbf{C}$ \\
\hline 1 & 20 & 10 & 0 & 10 \\
\hline 2 & 0 & 0 & 0 & 10 \\
\hline 3 & 10 & 0 & 0 & 0 \\
\hline Rataan & $\mathbf{1 0} \pm \mathbf{1 0}$ & $\mathbf{3 , 3 3} \pm \mathbf{5 , 7 7}$ & $\mathbf{0} \pm \mathbf{0}$ & $\mathbf{6 , 6 7} \pm \mathbf{5 , 7 7}$
\end{tabular}

Keterangan:

$\mathrm{K}=$ kontrol (tanpa temulawak); $\mathrm{A}=1 \mathrm{~mL} / \mathrm{kg}$ pakan; $\mathrm{B}=3 \mathrm{~mL} / \mathrm{kg}$ pakan; $\mathrm{C}=5 \mathrm{~mL} / \mathrm{kg}$ pakan

Tabel 3 menunjukkan rataan mortalitas ikan nilem paling tinggi terdapat pada perlakuan K yaitu sebesar $10 \%$, sedangkan yang paling rendah terdapat pada perlakuan B yaitu sebesar $0 \%$. Berdasarkan uji $\mathrm{F}$ analisis ragam (ANOVA satu arah) pada selang kepercayaan 95\%, diperoleh hasil bahwa pemberian perlakuan $\mathrm{A}, \mathrm{B}$ dan $\mathrm{C}$ dengan Kontrol (tanpa temulawak) tidak berbeda nyata terhadap mortalitas ikan nilem $(\mathrm{P}>0,05)$.

Selanjutnya diuji tantang kembali pada uji tantang kedua menggunakan bakteri $A$. hydrophila dengan dosis dinaikan 10 kali lipat dari $\mathrm{LD}_{50}$ yaitu menjadi $10^{8} \mathrm{sel} / \mathrm{mL}$. Mortalitas pada uji tantang kedua dapat dilihat pada Tabel 4. 
Tabel 4 Mortalitas (\%) benih ikan nilem pada uji tantang kedua

\begin{tabular}{ccccc}
\hline \multirow{2}{*}{ Ulangan } & $\mathbf{5}$ & $\mathbf{A}$ & $\mathbf{B}$ & $\mathbf{C}$ \\
\cline { 2 - 5 } & 30 & 10 & 40 & 10 \\
\hline 1 & 40 & 40 & 30 & 20 \\
\hline 2 & 60 & 30 & 20 & 30 \\
\hline 3 & $\mathbf{4 3 , 3} \pm \mathbf{1 5 , 3}$ & $\mathbf{2 6 , 7} \pm \mathbf{1 5 , 3}$ & $\mathbf{3 0} \pm \mathbf{1 0}$ & $\mathbf{2 0} \pm \mathbf{1 0}$ \\
\hline Rataan & \multicolumn{5}{c}{ Rataan } & mortalitas & ikan & nilem & paling
\end{tabular}

tinggi terdapat pada perlakuan $\mathrm{K}$ yaitu sebesar $43,3 \%$, sedangkan yang paling rendah terdapat pada perlakuan C yaitu sebesar $20 \%$. Berdasarkan uji $\mathrm{F}$ analisis ragam (ANOVA satu arah) pada selang kepercayaan 95\%, diperoleh hasil bahwa pemberian perlakuan $\mathrm{A}$, B dan $\mathrm{C}$ dengan Kontrol tidak berbeda nyata terhadap mortalitas ikan nilem $(\mathrm{P}>0,05)$.

\section{Kualitas Air}

Kualitas air selama percobaan menunjukkan kisaran suhu $28-29{ }^{0} \mathrm{C}, \mathrm{pH}$ 6,6 - 7,0 dan DO 4,0 - 4,6 mg/mL (Tabel 5), sehingga layak untuk kehidupan benih nilem.

Tabel 5 Parameter kualitas air

\begin{tabular}{ccccc}
\hline & \multicolumn{4}{c}{ Perlakuan } \\
\cline { 2 - 5 } Parameter & $\begin{array}{c}\mathrm{K} \\
(\text { Kontrol })\end{array}$ & $\begin{array}{c}\mathrm{A} \\
(1 \mathrm{~mL} / \mathrm{kg} \\
\text { pakan })\end{array}$ & $\begin{array}{c}\mathrm{B} \\
(3 \mathrm{~mL} / \mathrm{kg} \\
\text { pakan })\end{array}$ & $\begin{array}{c}\mathrm{C} \\
(5 \mathrm{~mL} / \mathrm{kg} \\
\text { pakan })\end{array}$ \\
\hline Suhu $\left({ }^{\circ} \mathrm{C}\right)$ & $28-29$ & $28-29$ & $28-29$ & $28-29$ \\
DO (ppm) & $4,0-4,3$ & $4,2-4,5$ & $4,0-4,2$ & $4,0-4,6$ \\
pH & $6,8-6,9$ & $6,8-7,0$ & $6,7-6,8$ & $6,6-6,9$ \\
\hline
\end{tabular}

\section{Gambaran Darah}

\section{Total sel darah putih (Leukosit)}

Total leukosit pada benih ikan nilem sebelum uji tantang pertama, setelah uji tantang pertama, dan setelah uji tantang kedua dapat dilihat pada Gambar 1.

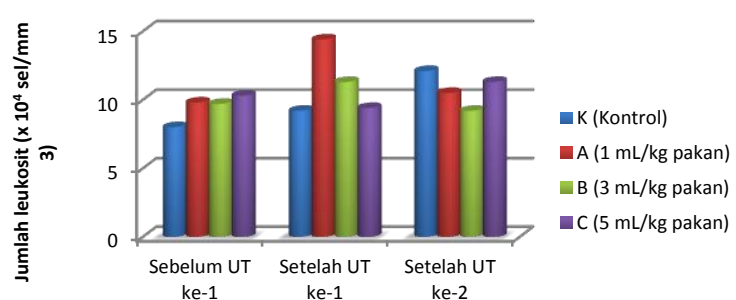

Gambar 1 Total sel darah putih benih ikan nilem selama penelitian

Nilai rataan total leukosit benih ikan nilem sebelum uji tantang pertama pada perlakuan K sebesar 8,0 x $10^{4} \mathrm{sel} / \mathrm{mm}^{3}$, perlakuan A sebesar 9,8 x $10^{4} \mathrm{sel} / \mathrm{mm}^{3}$, perlakuan B sebesar $9,7 \times 10^{4} \mathrm{sel} / \mathrm{mm}^{3}$, dan perlakuan C sebesar 1,03 x $10^{4} \mathrm{sel} / \mathrm{mm}^{3}$. Setelah uji tantang pertama rataan total leukosit pada K sebesar 9,2 × $10^{4} \mathrm{sel} / \mathrm{mm}^{3}$, perlakuan A sebesar 14,4 X $10^{4} \mathrm{sel} / \mathrm{mm}^{3}$, perlakuan B sebesar $11,3 \times 10^{4} \mathrm{sel} / \mathrm{mm}^{3}$, dan perlakuan C sebesar $9,4 \times 10^{4} \mathrm{sel} / \mathrm{mm}^{3}$. Setelah uji tantang kedua rataan leukosit pada $\mathrm{K}$ 12,1 x $10^{4} \mathrm{sel} / \mathrm{mm}^{3}$, perlakuan A $10,5 \times 10^{4} \mathrm{sel} / \mathrm{mm}^{3}$, perlakuan B $9,2 \times 10^{4} \mathrm{sel} / \mathrm{mm}^{3}$, dan perlakuan C $11,3 \times 10^{4} \mathrm{sel} / \mathrm{mm}^{3}$. Menurut Burhanuddin (2008), nilai leukosit pada ikan air tawar yang normal antara 20.000-150.000 sel/ $/ \mathrm{mm}^{3}$.

Berdasarkan uji F (ANOVA satu arah) pada selang kepercayaan 95\%, diperoleh hasil bahwa pemberian perlakuan A (1 g/kg pakan), B (3 g/kg pakan) dan C ( $5 \mathrm{~g} / \mathrm{kg}$ pakan) dengan Kontrol (tanpa temulawak) tidak berbeda nyata terhadap total leukosit ikan nilem $(\mathrm{P}>0,05)$.

\section{Kadar hemoglobin (Hb)}

Hasil perhitungan rataan kadar hemoglobin ikan nilem sebelum uji tantang 
pertama, setelah uji tantang pertama, dan terhadap kadar hemoglobin ikan nilem setelah uji tantang kedua disajikan pada $(\mathrm{P}>0,05)$.

Gambar 2.

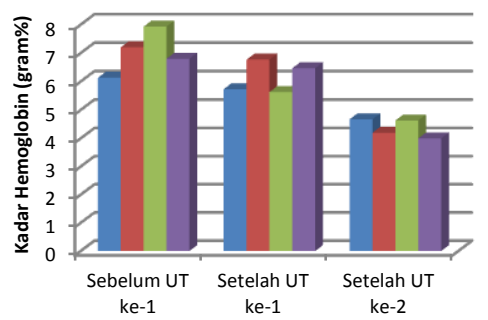

$\square \mathrm{K}$ (Kontrol)

- $\mathrm{A}(1 \mathrm{~mL} / \mathrm{kg}$ pakan)

B $(3 \mathrm{~mL} / \mathrm{kg}$ pakan $)$

- $\mathrm{C}(5 \mathrm{~mL} / \mathrm{kg}$ pakan)

Gambar 2 Kadar hemoglobin benih ikan nilem selama penelitian

Rataan kadar hemoglobin benih nilem sebelum uji tantang pertama pada perlakuan $\mathrm{K}$ sebesar 6,13 gram\%, perlakuan A sebesar 7,2 gram $\%$, perlakuan B sebesar 7,93 gram\%, dan perlakuan C sebesar 6,8 gram\%. Setelah uji tantang pertama rataan kadar hemoglobin pada perlakuan K sebesar 5,73 gram\%, perlakuan A sebesar 6,77 gram\%, perlakuan B sebesar 5,63 gram\%, dan perlakuan C sebesar 6,47 gram\%. Rataan kadar hemoglobin setelah uji tantang kedua pada perlakuan K sebesar 4,67 gram\%, perlakuan A sebesar 4,2 gram\%, perlakuan B sebesar 4,63 gram\%, dan perlakuan C sebesar 4 gram $\%$.

Rataan kadar hemoglobin pada ikan nilem normal adalah 7,8 gram\% (Andayani et al. 2014). Menurut Svobodova \& Vyukusova (1991) kadar hemogloblin pada ikan mas normal berada pada kisaran $(6-10 \mathrm{~g} \%)$. Berdasarkan uji $\mathrm{F}$ analisis ragam (ANOVA satu arah) pada selang kepercayaan 95\%, diperoleh hasil bahwa pemberian perlakuan A, $\mathrm{B}$ dan $\mathrm{C}$ dengan Kontrol tidak berbeda nyata

\section{Nilai hematrokit (Ht)}

Hasil perhitungan rataan nilai hematrokit ikan nilem sebelum uji tantang pertama, setelah uji tantang pertama, dan setelah uji tantang kedua disajikan pada Gambar 3.

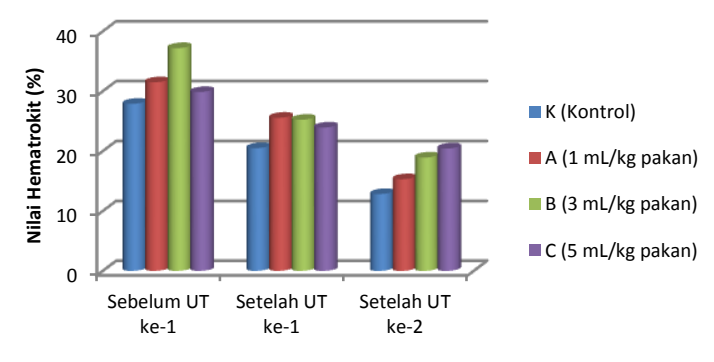

Gambar 3 Nilai hematokrit benih ikan nilem selama penelitian

Rataan nilai hematrokit sebelum uji tantang yang paling besar diperoleh pada perlakuan B sebesar 37,2\% dan terendah pada perlakuan K sebesar 27,9\%. Setelah uji tantang pertama rataan hematrokit terbesar diperoleh pada perlakuan A sebesar $25,57 \%$ dan terendah pada perlakuan K sebesar 20,5\%. Rataan hematrokit setelah uji tantang kedua terbesar diperoleh pada perlakuan C sebesar 20,43\% dan terendah pada perlakuan $\mathrm{K}$ sebesar $12,83 \%$.

Kadar hematokrit yaitu persentase volume sel darah merah pada ikan mas berkisar antara 28 - $40 \%$ (Svobodova \& Vyukusova 1991). Nilai hematrokit pada ikan nilem normal berkisar 33\% (Andayani et al. 2014). Berdasarkan uji $\mathrm{F}$ analisis ragam (ANOVA satu arah) pada selang kepercayaan 95\%, diperoleh hasil bahwa pemberian perlakuan A, 
B dan C dengan Kontrol tidak berbeda nyata terhadap nilai hematrokit ikan nilem $(\mathrm{P}>0,05)$.

\section{Pembahasan}

Bakteri A. hydrophila merupakan patogen yang menyebabkan penyakit bercak merah pada ikan. Yogananth et al. (2009) menegaskan bahwa bakteri A. hydrophila merupakan mikroorganisme akuatik yang berada di perairan laut maupun perairan tawar, dalam kondisi stress bakteri tersebut menjadi patogen dan bersifat patogen oportunistik pada penyakit Hemorrhagic septicemia pada ikan.

Mortalitas benih nilem yang diberi pakan dengan campuran larutan temulawak berbeda dosis kemudian di infeksi dengan $A$. hydrophila tingkat kematiannya lebih rendah dibandingkan dengan kontrol. Hal ini diduga karena temulawak berpengaruh terhadap sistem kekebalan tubuh ikan sehingga daya tahan tubuh ikan dapat meningkat dan tahan terhadap serangan bakteri A. hydrophila .

Mariyono dan Sundana

(2002) mengatakan bahan aktif yang terkandung pada temulawak antara lain kurkumin, minyak atsiri, saponin dan flavonoid dapat membunuh $A$. hydrophila dengan cara mendenaturasi protein dan merusak membran sel. Kandungan kimia temulawak terdiri dari flavonoid yang merupakan senyawa fenol dapat menghambat sintesis dinding sel (Mojab et al. 2008). Lebih lanjut Ardiansyah (2007) mengatakan bahwa secara umum mekanisme penghambatan mikroorganisme oleh saponin dapat disebabkan oleh beberapa faktor yaitu gangguan pada senyawa penyusun dinding bakteri, peningkatan permeabilitas membran sel yang dapat menyebabkan kehilangan komponen penyusun sel, menginaktivasi enzim, dan destruski atau kerusakan fungsi material genetik. Saponin juga bersifat spermisida, antimikrobia, anti peradangan dan memiliki aktivitas sitotoksik saponin juga bersifat pengelat berefek spasmolitik, yang dapat mengerutkan membran sel sehingga mengganggu permeabilitas sel. Akibat terganggunya permeabilitas, sel tidak dapat melakukan aktivitas hidup sehingga pertumbuhannya terhambat atau bahkan mati.

Perkembangan rataan sel darah putih benih nilem yang diamati selama penelitian pada Gambar 3 memperlihatkan rataan total leukosit sebelum uji tantang pada perlakuan A, $\mathrm{B}$, dan $\mathrm{C}$ lebih tinggi dibandingkan dengan kontrol, hal ini diduga pemberian temulawak kepada benih nilem memberikan pengaruh dalam peningkatan rataan leukosit. Setelah dilakukan uji tantang pertama terjadi perubahan total leukosit pada setiap perlakuan. Pada perlakuan $\mathrm{K}$, $\mathrm{A}$, dan $\mathrm{B}$ rataan total leukosit meningkat, sedangkan perlakuan $\mathrm{C}$ menurun. Rataan total leukosit setelah uji tantang kedua memperlihatkan peningkatan rataan total leukosit pada perlakuan $\mathrm{K}$ dan $\mathrm{C}$, sedangkan perlakuan A dan B terjadi penurunan.

Peningkatan jumlah leukosit benih nilem setelah uji tantang menunjukkan adanya penyakit infeksi tertentu yang menyerang ikan. 
Penyakit infeksi terjadi karena adanya antigen (A. hydrophila) yang masuk ke dalam tubuh ikan melalui penyuntikan. Leukosit berfungsi sebagai sistem pertahanan tubuh ikan yang bereaksi terhadap gangguan dari luar termasuk infeksi patogen. Menurut Abdullah (2008) peningkatan jumlah leukosit disebabkan oleh peningkatan jumlah limfosit, netrofil, monosit dan trombosit dalam darah ikan uji. Pada penelitian ini terjadi fluktuatif terhadap jumlah leukosit setelah diuji tantang dengan $A$. hydrophila. Menurut laporan Abdullah (2008) pada ikan lele, terjadinya penurunan jumlah leukosit setelah uji tantang karena meningkatnya kadar kortisol (memiliki efek immunosuppresor) dalam darah sebagai upaya ikan yang sakit memulihkan diri dari keadaan stress akibat infeksi A. hydrophila, penurunan limfosit juga diduga karena sel-sel limfosit berproliferasi membentuk sel $\mathrm{T}$ dan sel B yang didistribusikan ke situs luka dan infeksi untuk melisis dan menetralkan toksin dari antigen. Terjadinya peningkatan jumlah leukosit pada benih nilem dalam penelitian ini memberikan gambaran pertahanan tubuh nilem juga tinggi. Dengan pemberian temulawak pada benih nilem kemungkinan membantu sel leukosit dalam mengurangi jumlah dan patogenitas dari bakteri A. hydrophila.

Kadar hemoglobin $(\mathrm{Hb})$ pada masingmasing perlakuan dalam penelitian ini menunjukkan nilai yang fluktuatif, pada Gambar 4 menunjukkan setelah penyuntikan pertama bakteri A. hydrophila kadar $\mathrm{Hb}$ pada masing-masing perlakuan cenderung menurun, namun jumlahnya masih berada dalam kisaran kadar $\mathrm{Hb}$ normal (6 - $10 \mathrm{~g} \%$, mengacu pada $\mathrm{Hb}$ ikan mas). Diduga hal ini disebabkan kadar oksigen dalam darah menurun. Setelah penyuntikan kedua dengan bakteri $A$. hydrophila, kadar $\mathrm{Hb}$ pada masing-masing perlakuan menurun di bawah kisaran normal. Kadar hemoglobin dibawah kisaran normal mengindikasikan rendahnya kandungan protein pakan, defisiensi vitamin dan kualitas air buruk atau ikan mendapat infeksi, dalam hal ini ikan mendapat infeksi. Menurut Baehaqi et al. (2014) menurunnya nilai hemoglobin dalam darah berkaitan dengan rendahnya nilai eritrosit yang diduga karena ikan mengalami lisis di dalam darah. Lisis disebabkan oleh pecahnya sel darah merah karena adanya toksin bakteri di dalam darah yang disebut haemolisin. Toksin ini akan melisiskan hemoglobin dan melepaskan hemoglobin.

$$
\text { Anderson dan Siwicky }
$$

mengemukakan bahwa hematokrit merupakan persentase volume eritrosit dalam darah ikan yang hasil pemeriksaannya dapat digunakan sebagai patokan kondisi kesehatan ikan. Jumlah kadar hematrokit sebelum uji tantang dalam penelitian benih ikan nilem ini berkisar antara $27,90-37,20 \%$, setelah uji tantang pertama terjadi penurunan yang berkisar antara $20,50-25,57 \%$ dan terjadi penurunan kembali setelah uji tantang kedua yang berkisar antara 12,83 - 20,43\%. Hasil uji tantang menunjukkan nilai yang lebih rendah 
bila dibandingkan dengan kadar hematokrit pada ikan normal. Svobodova dan Vyukusova (1991) melaporkan bahwa kadar hematokrit pada ikan mas berkisar antara $28-40 \%$.

Penurunan kadar hematokrit ini diduga karena ikan mengalami anemia dan stress terhadap serangan A. hydrophila. Sesuai dengan pendapat Wedemeyer dan Yasutake (1977), menurunnya kadar hematokrit dapat dijadikan petunjuk mengenai rendahnya kandungan protein, defisien vitamin atau ikan mendapatkan infeksi. Gallaugher et al. (1995) menyatakan nilai hematokrit yang lebih kecil dari 22\% menunjukan ikan mengalami anemia. Kadar hematokrit juga dapat digunakan untuk mengetahui pengaruh dari pemakaian imunostimulan sehingga dapat digunakan sebagai petunjuk untuk mengetahui kondisi ikan setelah pemberian imunostimulan. Kuswardani (2006) mengungkapkan bahwa kadar hematokrit ini dapat bervariasi tergantung pada faktor nutrisi, umur, jenis kelamin, ukuran tubuh, dan masa pemijahan. Secara kualitatif, kadar hematokrit pada ikan perlakuan K (Kontrol) selalu lebih rendah dibanding dengan perlakuan uji lainnya mulai dari awal sampai akhir perlakuan. Rataan nilai hematokrit terbaik berada berada pada perlakuan B (3mL/kg pakan).

\section{KESIMPULAN}

Pemberian pakan yang mengandung temulawak tidak memberikan pengaruh yang signifikan $(\mathrm{P}>0,05)$ terhadap mortalitas dan gambaran darah benih ikan nilem.

\section{DAFTAR PUSTAKA}

Abdullah Y. 2008. Efektivitas Ekstrak Daun Paci-Paci Leucas lavandulaefolia Untuk Pencegahan Dan Pengobatan Infeksi Penyakit MAS Motile Aeromonad Septicaemia Ditinjau Dari Patologi Makro Dan Hematologi Ikan Lele Dumbo Clarias sp. [Skripsi]. Departemen Budidaya Perairan, Fakultas Perikanan dan Ilmu Kelautan, Institut Pertanian Bogor. Bogor

Andayani S, Marsoedi, Sanoesi E, Wilujeng AE, Suprastiani H. 2014. Profil Hematologis Beberapa Spesies Ikan Air Tawar Budidaya. [Jurnal] Green technology 3. Fakultas Sains dan Teknologi UIN Maliki Malang.

Anderson DP, Siwicky AK. 1993. Basic Haematology and Serology for Fish Health Program. Paper Presented in Second Symposium on Disease in Asia Aquaculture Aquatic Animal Health and Eviroment Phuket Thailand.

Angka SL. 2004a. Pemanfaatan Fitofarmaka untuk Pencegahan dan Pengobatan Penyakit MAS (Motile Aeromonad Septicemia) pada Ikan Lele Dumbo Clarias sp. [Jurnal] Gokuryoku Vol. 10.

Ardiansyah. 2007. Antimikroba dari Tumbuhan. Tohoku University Sendai. Jepang. 83 Hal.

Baehaqi DK, Ramadhina GD, Rahayu IS, Satria MB, Putra MF. 2014. Pengaruh Bakteri terhadap Profil Darah Ikan Nila (Oreochromis niloticus) dan Ikan Gurame (Osprhronemus gouramy) serta Pengaruh Pemberian Pakan terhadap Profil Darah Ikan Lele Dumbo (Clarias gariepinus). [Skripsi] Jurusan Perikanan dan Kelautan, Universitas Jenderal Soedirman. Purwokerto.

Burhanuddin AI. 2008. Peningkatan Pengetahuan Konsepsi Sistematika dan Pemahaman Sistem Organ Ikan yang Berbasis SCL Pada Mata Kuliah 
Ikhtiologi. [Laporan Modul Pembelajaran Berbasis SCL]. Fakultas Ilmu Kelautan dan Perikanan Universitas Hasanuddin. Makassar.

Cholik F, Jagatraya AG, Poernomo RP, Jauzi A. 2005. Akuakultur: Tumpuan Harapan Masa Depan Bangsa. Masyarakat Perikanan Nusantara dan Taman Akuarium Air Tawar-TMII, Jakarta.

Effendie MI. 1997. Biologi Perikanan. Yogyakarta (ID): Yayasan Pustaka Nusantara.

Gallaugher PH, Thorarensen H, Ferrel AP. 1995. Hematocrit in Oxygen Transport and Swimming in Rainbow Trout Oncorhyncus mykiss. Respiration Physiology. 102:279-292.

Hesser EF. 1960. Methods for Routine Fish Hematology. Progessive Fish Culturist.

Kamiso HN. 1993. Hasil-hasil penelitian dan Proyek penelitian Bioteknologi dalam Mendukung Program pengembangan Budidaya Perairan. Laporan penelitian. Cisarua. Bogor.

Mariyono, Sundana. 2002. Teknik pencegahan dan pengobatan penyakit bercak merah pada ikan air tawar yang disebabkan oleh bakteri Aeromonas hydrophila. Buletin Teknik Pertanian. Badan Litbang Pertanian. Jakarta. 36 Hal.

Melisa. 2008. Uji Altifitas Anti Bakteri dan Formulasi Dalam Sediaan Kapsul Dari Ekstrak Etanol Rimpang Temulawak Terhadap Beberapa Bakteri.[Skripsi]. Fakultas Farmasi Universitas Sumatera Utara, Medan. 61 Hal.

Mojab F, Poursaeed M, Mehrgan H, Pakdaman S. 2008. Antibacterial Activity of Thymus daenensis methanolic Extract. Pak. J. Pharm. Sci.: 210-213.

Sari NW, Lukistyowati I, Aryani N. 2012. Pengaruh Pemberian Temulawak (Curcuma Xanthorriza Roxb) Terhadap Kelulushidupan Ikan Mas (Cyprinus Carpio L) Setelah Di Infeksi Aeromonas hydrophila. Jurnal Perikanan dan Kelautan: 43 - 59.

Still RG, Torrie JH. 1991. Prinsip dan Prosedur Statistika : Suatu Pendekatan Biometik. Jakarta : Gramedia Pustaka Utama.

Svobodova Z, Vyukusova B, 1991. Diagnostic, Prevention and Therapy of Fish Disease and Intoxication. Research Institute of Fish Culture and Hydro biology Vodnany Czechoslovakia. Tersedia pada: http//www.fao.org/fi/website/firetriveacti on.do?dom=topic \&fid $=16064 \&$ lang=en [24 September 2014, 09.30].

Wedemeyer GA, Yasutake WT. 1977. Clinical Methods for the Assessment of the Effect Environment Stress on the Fish Health. US Depart of the Interior Fish and Wildlife Service. 89:1-17.

Yani ME, Riauwaty M, Lukityowati I. 2012. Sensitivitas Temulawak (Curcuma xanthorrhiza Roxb) Terhadap Pertumbuhan Aeromonas hydrophila. [Jurnal]. FPIK Universitas Riau: Riau.

Yogananth N, Bhakyaraj R, Chanthuru A, Anbalagan T, Nila M. 2009. Detection of Virulence Gene in Aeromonas hydrophila Isolates from Fish Samples Using PCR Thecnique. Global Journal of Biotechnology and Biochemistry 4 (1): 51-53. 